\section{References}

[1] Wesslau, H., Makromol. Chem. 20, 111 (1956).

[2] Francis, P., Cooke, R., Jr., and Elliott, J., J. Polymer Sci. 3 1, 453 (1958).

[3] Kotera, A., et al., Rept. Progr. Polymer Phys. Japan 3, 58 (1960).

[4] Chiang, R., J. Polymer Sci. 36, 91 (1959).

[5] Tung, L., J. Polymer Sci. 36, 287 (1959).
[6] de la Cuesta, M., and Billmeyer, F. Jr., J. Polymer Sci. A 1, 1721 (1963).

[7] Hoeve, C. A. J., Wagner, H. L., and Verdier, P. H., J. Res. Nat. Bur. Stand. (U.S.), 76A (Phys. and Chem.), No. 2, 137-140 (Mar.-Apr. 1972). Paper I of this series.

[8] Allen, P. W., Techniques of Polymer Characterization, p. 180 (Butterworths, London, 1959).

(Paper 76A2-710)

\title{
The Characterization of Linear Polyethylene SRM 1475. VI. Preparation of Calibrating Fractions
}

\author{
Richard G. Christensen \\ Institute for Materials Research, National Bureau of Standards, Washington, D.C. 20234
}

(December 15, 1971)

\begin{abstract}
Fractions for use in calibrating a gel permeation chromatograph were prepared by a Desreux column extraction method. The construction and operation of the fractionating system are described.
\end{abstract}

Key words: Column extraction fractionation; fractionation; linear polyethylene.

\section{Introduction}

In the process of determining the molecular weight distribution of SRM $1475[1]^{1}$ it was necessary to calibrate a gel permeation chromatograph [2] with linear polyethylene. Fractions of linear polyethylene were used for this purpose. The fractions were subsequently used to establish relations between limiting viscosity number (intrinsic viscosity) and molecular weight [3]. The requisite fractions were prepared by a column extraction [4] technique, using a solvent system which has been described in considerable detail by Chiang [5] and others.

\section{Experimental Procedure}

The fractionation apparatus was constructed as depicted in figure 1 . The column temperature is maintained by surrounding it with a narrow, deep oil bath, $20 \times 20 \times 90 \mathrm{~cm}$. The stirrer and heater are placed inside a long tube to promote efficient thermal exchange between the top and bottom of the tank.

The solvent inlet to the column is a small concentric tube reaching to the bottom of the packed column. The efflux collects above the column packing and is periodically drawn off through a slightly larger tube concentric with the inlet tube. The liquid is forced out by nitrogen pressure. The $8 \mathrm{~cm}$ diameter column is packed

\footnotetext{
${ }^{1}$ Figures in brackets indicate the literature references at the end of this paper.
}

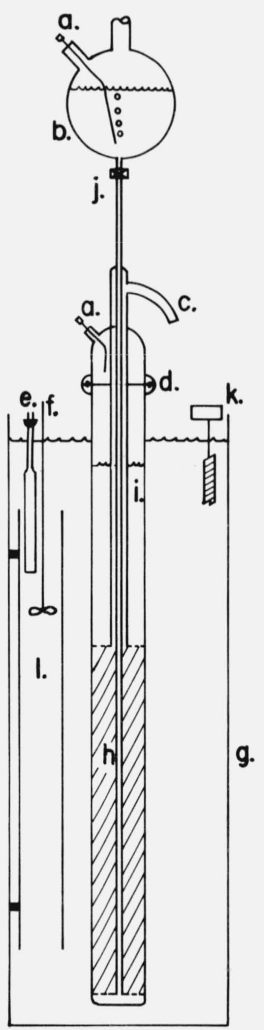

FigURE 1. Section of fractionation apparatus.

(a) nitrogen inlets; (b) preheating flask; (c) efflux siphon; (d) o-ring flange; (e) heater; (f) stirrer; (g) tank; (h) packed column; (i) effluent liquid; (j) inlet tube; (k) thermoregulator; (l) circulating tube. 
with Johns-Manville Celite No. $545^{2}$ to a depth of about $55 \mathrm{~cm}$. The free liquid volume of the packed column is about $2000 \mathrm{~cm}^{3}$.

In operation, the column was heated to $127^{\circ} \mathrm{C}$, the polymer in xylene was allowed to flow in, and the column was allowed to cool slowly overnight. All of the polyethylene except a small amount of low molecular weight was thereby precipitated in the column. The cooling rate at $90{ }^{\circ} \mathrm{C}$ was about $0.2^{\circ} \mathrm{C} / \mathrm{min}$. The cooled $\left(50^{\circ} \mathrm{C}\right)$ xylene was displaced by a poor solvent, 2 butoxyethanol, while the precipitated polyethylene was retained in the column. The column was reheated to $127^{\circ} \mathrm{C}$, causing the polyethylene to melt and swell with the poor solvent. The column was then extracted with mixtures of xylene and 2-butoxyethanol which were successively better solvents. The solutions of extracted polyethylene were siphoned into flasks containing cold ethanol. The polyethylene was filtered out, washed with ethanol, air dried, and then dried in vacuum at $50^{\circ} \mathrm{C}$.

All solvents contained 0.1 percent Ionol (2,6-ditert.-butyl-4-methylphenol) as an antioxidant. They were preheated under nitrogen to over $130^{\circ} \mathrm{C}$ before being admitted to the column. This served to degas the solvent, preventing the formation of bubbles in the column. Typical input concentration was 1 percent

${ }^{2}$ Certain commercial equipment, instruments, or materials are identified in this paper in order to adequately specify the experimental procedure. In no case does such identification imply recommendation or endorsement by the National Bureau of Standards, nor does it imply that the material or equipment identified is necessarily the best available for the imply that
purpose. polymer in xylene. Extracting mixtures were 15-55 percent xylene. Recovery was ordinarily 97-98 percent, but no great effort was made to obtain absolutely quantitative recovery of material.

Samples PE 7 to PE 180 were prepared by fractionating SRM 1475. Yield was three to six grams of each sample. Samples PE 200 to PE 600 were prepared from Phillips Marlex 6002. These fractions contained two to four grams each.

Light-scattering [6], osmometry [7], and gel permeation chromatography [2] studies were carried out with these samples. The final results are tabulated in paper $\mathrm{X}$ of this series [2].

\section{References}

[1] Hoeve, C. A. J., Wagner, H. L., and Verdier, P. H., J. Res. Nat. Bur. Stand. (U.S.), 76A, (Phys. and Chem.), No. 2, 137-140 (Mar--Apr. 1972). Paper I of this series.

[2] Ross, G. S., and Frolen, L. J., J. Res. Nat. Bur. Stand. (U.S.), 76A, (Phys. and Chem.) No. 2, 163-170 (Mar--Apr. 1972). Paper $\mathrm{X}$ of this series.

[3] Hoeve, C. A. J., and Wagner, H. L., to be published.

[4] Desreux, V., Rec. Trav. Chim. 68, 789 (1949).

[5] Chiang, R., J. Polymer. 36, 91 (1959).

[6] Frolen, L. J., Ross, G. S., Wims, A. M., and Verdier, P. H., J. Res. Nat. Bur. Stand. (U.S.), 76A, (Phys. and Chem.), No. 2, 156-160 (Mar--Apr. 1972). Paper VIII of this series.

[7] Brown, J. E., and Verdier, P. H., J. Res. Nat. Bur. Stand. (U.S.), 76A, (Phys. and Chem.), No. 2, 161-163 (Mar-Apr. 1972). Paper IX of this series.

(Paper 76A2-711) 